\title{
CERITA PANJI DALAM PERSPEKTIF SEJARAH
}

Sunu Catur Budiyono

\begin{abstract}
As a story which spread is dominated by oral tradition, Panji is presented in various versions. Meanwhile, history uses facts, data, or documents to be systematically explored and elaborated. In this case, history speaks in the domain of "the logic of acceptability" whereas literature extends into the realm of "the logic of ignorance". If literature and history serve the phrase "bistorical literature" and "literary history" then two things are different. Historical literature is part of a literary history study, but not the other way around. History literature stems from the belief of something. Instead, history begins with the proof of something (Ibrabim, 1986: vii). The story of Panji is also the only local story that is globalized. Panji is also appointed as a cultural hero of the archipelago. Starting from the above discussion, it is stated that historical literature can only be used to give an overview of civilization society, the concept of state administration, and the style of thinking in that era.
\end{abstract}

Keywords: Panji, history, literatures, local stories

\section{PENDAHULUAN}

Sastra dan sejarah merupakan dua hal yang berbeda. Di satu sisi mereka bisa berbarengan tetapi di sisi lain mereka bertolak belakang. Sastra merupakan karya imajinatif walaupun ia menggunakan kenyataan sebagai bahan yang diolah melalui proses kreatif pengarang. Sastra mengutamakan proses imajinatif dan kreatif dengan muatan nilai atau norma tertentu. Logika dalam sastra adalah "logika imajinatif" yang berbicara tentang dunia kemungkinan. Dengan demikian, logika dalam sastra sering kali tidak berbanding lurus dengan logika kehidupan sehari-hari. Akan tetapi, kita tetap bisa menerima logika tersebut karena kita menyadari bahwa yang kita baca atau dengar itu adalah sastra. Bahkan sebagian ahli mengatakan bahwa semakin lebar "jarak tegangan” antara kenyataan dan karya imajinatif yang kita nikmati semakin "bagus" karya itu.
Sementara itu, sejarah menggunakan fakta, data, atau dokumen untuk dieksplorasi dan dielaborasi secara sistematis logis. Berbicara sejarah "seakan-akan" kita berbicara tentang kenyataan secara obyektif. Walaupun demikian, sesuatu yang tidak bisa disangkal adalah penulisan sejarah masa lampau juga penuh dengan “imajinatif”. Sejarawan melalui imajinasinya merekonstruksi masa lampau itu berdasarkan data yang ada pada saat ini. Oleh karena itu, tafsir atau sejarah masa lampau sesungguhnya juga merupakan karya "imajinatif” yang kita sebut “obyektif” itu. Dalam hal ini, sejarah berbicara dalam ranah "logika keberterimaan" sedangkan sastra dalam batas tertentu masuk ranah "logika ketakberterimaan".

Jika sastra dan sejarah dijadikan frasa "sastra sejarah" dan "sejarah sastra" maka menjadi dua hal yang berbeda. Sastra sejarah merupakan bagian dari kajian sejarah sastra, 
tetapi tidak sebaliknya. Sastra sejarah dalam batas tertentu masuk ranah "logika ketakberterimaan" sedangkan sejarah sastra berada dalam ranah "logika keberterimaan". Karena sejarah harus bersifat saintifik, humanistik, rasional, kritis, dan self revealatory.

Sastra sejarah "tidak dapat" digunakan sebagai sumber sejarah yang valid/akurat, karena adanya perbedaan penulisan antara sastra sejarah dengan sejarah yang sebenarnya. Apa yang dilukiskan dalam sastra sejarah belum tentu merupakan kebenaran. Terdapat campur-aduk antara fakta dan imajinasi walaupun mungkin peristiwa yang dipaparkan benar-benar terjadi. Sastra sejarah ditulis berdasarkan imajinasi penulisnya, sedangkan sejarah ditulis berdasarkan fakta (interpretasi atas fakta). Sastra sejarah bermula dari kepercayaan adanya sesuatu. Sebaliknya, sejarah bermula dengan pembuktian adanya sesuatu (Ibrahim, 1986:vii).

\section{DASAR TEORITIS}

\section{1) Cerita Panji dan Latar Sejarah ${ }^{1}$}

Sastra sejarah dalam tradisi nusantara banyak ragamnya, beberapa kakawin dapat digolongkan dalam sastra sejarah, antara lain Desawarnana oleh Empu Prapanca dan Pararaton. Dalam sastra Jawa Pertengahan antara lain kidung Ronggo Lawe dan kidung Surandaka. Dalam sastra Jawa Baru dikenal ada babat, antara lain Babat Mentawis, Babat Diponegoro, dan Babat Tanah Jawi. Dalam sastra Melayu terdapat hikayat/sejarah, antara

\footnotetext{
${ }^{1}$ Dialog interaktif budaya "Aspek Keteladanan Pada Cerita Panji” 14 Februari 2018, bersama LPIK UNIPA Surabaya
}

lain Hikayat Raja-Raja Pasai dan Sejarah Melayu. Walaupun demikian, tidak berarti bahwa sastra sejarah tersebut dengan serta-merta dapat secara langsung digunakan sebagai "kanon" dalam penulisan sejarah.

Bagaimana dengan cerita panji; apakah cerita panji ditulis sebagai sastra sejarah? Apakah panji sebagai cerita fiktif yang ditulis berlatar sejarah tertentu? Apakah cerita panji merupakan cerita imajinatif semata? Pertanyaan-pertanyaan tersebut dari sudut tertentu terasa problematis dan pelik untuk dijawab.

Sebagai suatu cerita yang penyebarannya didominasi oleh tradisi lisan, Panji hadir dalam berbagai versi. Demikian pula, cerita Panji disajikan dalam berbagai bentuk ekspresi seni, baik seni pertunjukkan, tuturan/lisan, maupun sastra (tulis). Pun nama tokoh utama (Raden Panji) dan (Galuh Candra Kirana) diberi nama pribadi dalam berbagai versi cerita Panji, misalnya untuk Panji diberi nama Wira Namtani dalam Waseng, Makaradwaja dalam Wangbang Wideya, Nusapati dalam Malat; untuk Galuh diberi nama Amahi Lara dalam Waseng, Warastrasari dalam Wangbang Wideya, Anrang Kesari dalam Malat. Dengan kata lain, versi dan bentuk kisah Panji telah mengalami perkembangan yang kemudian dipengaruhi oleh cerita rakyat setempat.

Cerita panji ditulis dalam bahasa Jawa Pertengahan bermetrum kidung/tembang macapat dan berkembang pada masa kejayaan kerajaan Majapahit di Jawa Timur (Bandem, 1996:43). Menurut Zoetmulder (1985:532-533) bentuk kakawin dalam bahasa Jawa Kuna 
merupakan media ungkap untuk epos-epos dari India; sedangkan kidung dan bahasa Jawa Pertengahan secara eksklusif dipakai untuk menyajikan kisah-kisah Panji. Selanjutnya ditegaskan oleh Zoetmulder bahwa tidak satu kakawin pun yang menampilkan kisah Panji. Demikian pula sebaliknya bahwa dalam sastra kidung jarang dijumpai menyajikan epos-epos dari India. Karena kisah Panji berkembang pada masa kejayaan kerajaan Majapahit, maka bisa dipahami kalau kisah ini menyebar ke seluruh wilayah kerajaan Majapahit, seperti Sumatra, Kalimantan, Sulawesi, Bali, Lombok, Wanin, Seran, bahkan sampai ke Semenanjung Melayu, Thailand, dan Kamboja (Poerbatjaraka). Hal ini selaras dengan "wilayah" kerajaan Majapahit (Desawarnana pupuh XIII-XV). Kisah Panji juga merupakan satu-satunya cerita lokal yang mengglobal. Panji juga diangkat sebagai pahlawan budaya nusantara.

Pandangan senada dikemukakan Kieven (2014) bahwa kisah Panji harus dipertimbangkan dalam konteks karakter kakawin dan kidung, serta oposisi biner antara kedua genre sastra itu. Cerita dalam kakawin berkonotasi sakral, suci (para tokohnya banyak berhubungan dengan dewa atau terlibat dalam praktik asketis). Kidung menggunakan karakter lebih membumi, menampilkan latar Jawa yang gamblang, dan (menyebut nama dan latar geografis yang jelas; Jenggala dan Panjalu). Walaupun demikian, kakawin dan kidung memiliki kesamaan yakni berlatar belakang istana sehingga menjadi bagian dari kanon sastra istana.
Terkait dengan kisah Panji sebagai kanon sastra istana, menimbulkan pertanyaan di kalangan para ahli sastra/budaya. Apakah kisah Panji awalnya diciptakan sebagai sastra rakyat dan kemudian diadopsi oleh sastra istana? Atau sebaliknya, apakah cerita Panji semula diciptakan sebagai sastra istana kemudian diadopsi sebagai sastra rakyat? Jika kemungkinan kedua diterima maka menjadi kontradiktif terkait dengan penggambaran Panji dalam relief; apakah materi sakral ditransfer ke media budaya rakyat atau tradisi rakyat ditransfer ke media sakral? (Kieven, 2014:33-34).

Pertanyaan lain terkait cerita Panji adalah menyangkut latar belakang historisnya, yang menghasilkan pendapat berbeda-beda, kompleks, dan pelik. Dalam hal ini, setidaktidaknya terdapat tiga pendapat utama, yakni pertama, Rasser ia berpendapat bahwa cerita Panji terkait dengan kehidupan raja Airlangga raja dari Kahuripan yang membagi kerajaannya menjadi dua yakni Jenggala dan Kediri. Akan tetapi, pada akhirnya Rasser menolak pendapatnya ini dengan menyatakan bahwa sosok Panji tidak dapat diidentikkan dengan satu sosok historis saja. Kedua, Poerbatjaraka berpandangan bahwa Raja Kameswara dari kediri merupakan prototipe dari Panji. Poerbatjaraka mengacu pada kakawin Smaradahana yang digubah pada abad 12 untuk menghormati Raja Kameswara dari Kediri dan istrinya Kirana dari Jenggala. Ketiga, Berg berpendapat bahwa prototipe cerita Panji adalah Raja Hayam Wuruk. Pandangan ini didasarkan pada Kidung Sunda yang menyebutkan bahwa 
ayah Hayam Wuruk adalah Pangeran dari Koripan. Pembahasan Berg (1974) mengenai cerita Damarwulan (salah satu versi cerita Panji) juga menganggap sebagai representasi dari episode kerajaan Majapahit.

Bertolak dari beberapa pendapat di atas, Kieven (2014) menyatakan bahwa untuk melihat historisitas Panji maka nama empat kerajaan dan sinonimnya yang terdapat dalam cerita Panji. Nama-nama kerajaan tersebut (1) Jenggala/Kuripan, (2) Daha/Kediri/Mamenang sebagai kerajaan asal Panji dan Kerajaan asal Candrakirana, (3) Singasari/Tumapel, dan (4) Gegelang/Urawan/Wengker. Dalam cerita Panji, berbagai kerajaan tersebut Saling berkaitan dalam jaringan rumit kekerabatan. Selain itu, Desawarnana memberikan bukti bahwa nama Kuripan, Singasari, Daha, dan Wengker menjadi bagian dari gelar penguasa atau pangeran/putri yang menjadi anggota, atau terkait dengan anggota keluarga kerajaan. Oleh karena itu, cerita Panji merupakan bagian utama dari pemikiran politik istana Majapahit.

Menurut Kieven, hal mendasar untuk memahami Panji adalah terpisahnya dua tokoh protagonis cerita Panji dan pertemuan kembali mereka di akhir kisah. Hal ini memiliki kesesuaian yang tak terbantahkan dengan pembagian kerajaan menjadi Jenggala dan Kediri, serta penyatuannya dikemudian hari.

Pendapat lain terkait dengan cerita Panji dikemukakan oleh J.J. Ras (Kieven, 2014) yang melihat mitologis cerita Panji. Ras menyatakan bahwa cerita Panji sebagai "cerita pernikahan" khas yaitu petualangan dua tokoh protagonis "dipentaskan pada perayaan khidmat perkawinan mereka sendiri”. Hal ini sejalan dengan Pararaton yang menyatakan bahwa Raja Hayam Wuruk ketika masih muda juga sebagai penari topeng.

\section{2) Simbolisme Cerita Panji}

a) Cerita Panji melambangkan erotisme dan penyatuan seksual.

Menurut Supomo (Kieven, 2014) penyatuan Kama dan Ratih dalam kakawin sesungguhnya sejajar dengan penyatuan Panji dan Candrakirana dalamm cerita Panji, masing-masing pada tingkatan spiritualitasnya sendiri.

b) Cerita Panji melambangkan kesuburan

Dalam mitologi Jawa, Panji dan Candrakirana dianggap sebagai tititsan dewa Wisnu dan permaisurinya, Sri. Kemanunggalan mereka melambangkan kesuburan. Dalam hal ini, kaka beradik Sri dan Sadono, dapat dibandingkan dengan Panji dan Candrakirana sebagai titisan Wisnu dan Dewi Sri. Sedangkan Ras, menafsir Panji sebagai titisan Wisnu yang melambangkan matahari sekaligus air, Candrakirana sebagai titisan Sri yang melambangkan bumi. Panji disamakan dengan pohon kehidupan, yang melambangkan lingga Siwa yang menyemburkan mani dan menyuburkan yoni permaisuri Siwa 
c) Cerita Panji melambangkan penyatuan politis

Salah satu simbolisme Panji terletak pada representasi tentang penyatuan kerajaan. Perjuangan penyatuan kerajaan tersebut pada zaman Majapahit merupakan tema utama sehingga meningkatkan popularitas cerita Panji pada waktu itu.

d) Cerita Panji melambangkan perjuangan politik pangeran muda

Subyek kidung dan cerita Panji bukanlah tahta itu sendiri melainkan perswiapan naik tahta kerajaan. Dalam persiapan menjadi pria ideal, Panji harus menunjukkan kualitasnya dalam berbagai bidang: praktik berkesenian, peperangan, bercinta, dan praktik asketis. Sebagai seorang Pangeran, Panji hanya cukup mumpuni untuk menjadi raja setelah menikahi wanita yang sederajat. Oleh karena itu, cerita Panji mencerminkan perjuangan politik dan perjuangan status seorang calon-raja muda dalam hierarki kerajaan.

\section{HASIL KAJIAN DAN PEMBAHASAN}

Bertolak dari pembahasan di atas, maka dinyatakan bahwa sastra sejarah hanya dapat digunakan untuk memberi gambaran peradaban masyarakat, konsep ketatanegaraan, dan corak pemikiran pada zaman itu. Oleh karena itu, terdapat beberapa hal yang harus kita pahami bahwa (1) pemahaman tentang sejarah dalam konteks tradisional masa lampau berbeda dengan sejarah dalam arti modern. Sejarah dalam konteks tradisional masa lampau campur aduk antara kebenaran, mitos, dan legenda. Dalam hal ini "sejarah" sebagai afirmasi atas kekuasaan raja. Pembacaan Nancy (2003) atas Babad Jaka Tingkir menegaskan tesis ini. (2) hampir semua tulisan (teks) masa lampau disampaikan dalam bentuk sastra. Sesuai dengan kodratnya bahwa sastra penuh dengan ekspresi puitik dan pasemon. Oleh karena itu, pemahaman kebenaran dalam sastra harus dipahami dalam kaidah tersebut.

\section{PENUTUP DAN KESIMPULAN}

Seni pertunjukkan memiliki peran penting dalam tradisi masyarakat Jawa Kuna, sebagaimana diilustrasikan dalam prasasti, relief, maupun sastra. Dalam Desawarnana dan Pararaton berbicara tentang pertunjukan tari dan drama, bahkan raja sendiri yang menjadi aktornya. Terkait cerita Panji, tradisi pertunjukkannya dimainkan di istana maupun lingkungan pedesaan. Hal ini menimbulkan pertanyaan; apakah tradisi Panji berakar pada tradisi rakyat atau tradisi istana? Pertanyaan yang sama rumitnya adalah; dapatkah kita menentukan apakah keberadaan dramatik cerita Panji mendahului bentuk sastranya?

Setiap cerita memiliki riwayat masingmasing. Serat Pranacitra (Rara Mendut) berasal dari lisan ke tulisan. Sebaliknya, serat Damarwulan berasal dari tulisan ke lisan. 


\section{DAFTAR PUSTAKA}

Bandem, I Made dan Sal Murgianto

1996. Teater Daerah Indonesia. Kanisius:

Yogyakarta.

Berg, Cornelis Christian.

1974. Penulisan Sejarah Jawa. Bhratara: Jakarta.

Brandon, James R.,

1974. Theater In Southeast Asia. Harvard University Press. Massachusetts.

Florida, Nancy K.

2003. Menyurat yang Silam Menggurat yang Menjelang: Sejarah sebagai Nubuat di Jawa Masa Kolonial. Bentang Budaya: Yohyakarta.

Holt, Claire.

2000. Melacak Jejak Perkembangan Seni di Indonesia. Masyarakat Seni Pertunjukkan Indonesia: Bandung.

Ibrahim, Zahrah.

1986. Sastera Sejarah: Interpretasi dan Penilaian.

Dewan Bahasa dan Pustaka: Kuala Lumpur.

Kieven, Lydia.

2014. Menelusuri Figur Bertopi Dalam Relief Candi Zaman Majapabit: Pandangan Baru terhadap Fungsi Religius Candi-Candi Periode Jawa Timur Abad ke-14 dan ke-15. Ecole
Frncaise d'Extreme-Orient, Gramedia: Jakarta.

Poerbatjaraka, R.M. Ng.

1968. Cerita Panji dalam Perbandingan. Gunung Agung. Jakarta.

Rahardjo, Supratikno.

2002. Peradaban Jawa: Dinamika Pranata Politik, Agama, dan Ekonomi Jawa Kuno. Komunitas Bambu: Jakarta.

Zoetmulder, P.J.

1985. Kalangwan: Sastra Jawa Kuno Selayang Pandang. Djambatan: Jakarta. 